\title{
LEGUME AND FERTILIZER NITROGEN IN NEW ZEALAND PASTORAL FARMING
}

\author{
ROGER BALL \\ Grasslands Division, DSIR, Palmerston North
}

\begin{abstract}
The role of clovers in grass/clover pastures is discussed. Their nitrogen-fixing capacity and direct contribution to yield are greatly modified by climate, nutrient supplies and soil nitrogen availability. A ceiling to production from grass/clover pastures is envisaged where the application of fertilizer nitrogen will be required for further increases in productivity using present species. Satisfactory short-term pasture responses to nitrogen have been measured. Modification of these by climatic, pastoral and managerial factors is discussed. The long-term implications of nitrogen usage on pastures are not clear. More research is required before the place of fertilizer nitrogen for forage production in New Zealand pastoral farming can be properly assessed.
\end{abstract}

\section{INTRODUCTION}

NITROGEN is no more essential than any other element required for plant growth. Nevertheless, nitrogen is unique. Worldwide, more, crops are deficient in nitrogen than any other nutrient (Viets, 1965) and a critical factor in future world food production will be the energy input for nitrogen fixation, whether biological or chemical (Anon., 1969).

The nutrients required for $10,000 \mathrm{lb}$ of grass dry matter are roughly equivalent to:

nitrogen in $17 \mathrm{cwt}$ of sulphate of ammonia;

potassium in $7 \mathrm{cwt}$ of muriate of potash;

phosphorus and sulphur in $2 \mathrm{cwt}$ of superphosphate; and .- magnesium in $2 \mathrm{cwt}$ of magnesium sulphate.

The soil must provide relatively large quantities of nitrogen for vigorous growth of pasture grasses.

\section{CLOVERS AS A NITROGEN SOURCE IN MIXED PASTURES}

Fertilizer usage in New Zealand grassland farming is almost entirely confined to the application of non-nitrogenous fertilizers, 
and lime, to grass/clover pastures. Clovers, particularly white clover, are relied on to provide nitrogen for grass growth. Once established and effectively nodulated, with satisfactory mineral nutrition clovers can obtain their nitrogen for growth through symbiosis with rhizobial bacteria. They are not directly dependent on soil nitrogen.

The nitrogen cycle in the New Zealand grass/clover-grazing animal complex has been described (Sears, 1956, 1960; Walker, 1956, 1962; O'Connor, 1966). A small proportion of the nitrogen fixed by clovers becomes available to grasses by underground transfer, mostly following the decay of clover roots and nodules (Butler and Bathurst, 1956; Dilz, 1965). Between 70\% (Sears ef al., 19.65) and 80\% (Vincent, 1965) of the nitrogen fixed in the root nodules is translocated to the above-ground parts of the plant. Most of this clover nitrogen returns to the soil in animal urine, with some attendant losses (Doak, 1952). It is then readily available to grasses which, unlike clovers, are entirely reliant on the soil for nitrogen.

A recent discussion of the dynamics of New Zealand pasture productivity considered the input, cycling and conservation of nitrogen as the ultimate limiting factor to pasture productivity, within the limits set by climate, species and management (O’Connor, 1966).

During the period of the year when clovers grow vigorously, they are expected to fix sufficient nitrogen to meet the requirements of grasses and to replace nitrogen lost from the soil-plant system. A well managed ryegrass/white clover pasture in the Manawatu produces some 10 to $13,000 \mathrm{lb}$ D.M./acre each year (Sears ef al., 1965; Brougham and Ball, unpublished data) with a considerably greater potential (Brougham, 1966). Its European counterpart produces only 4 to $7,000 \mathrm{lb}$ D.M./acre annually (Dilz, 1965; Cooke, 1967). The comparative success of New Zealand's grass/clover associations is partly attributable to the very high levels of nitrogen fixation possible in this climate. Sears measured 600 units of nitrogen per acre fixed each year by white clover (Sears et al., 1965). Overseas results of 100 to 200 units/acre are much lower (Cooke, 1967). A unit of nitrogen is the equivalent of a pound of elemental nitrogen.

\section{Some Factors Affecting Nitrogen Fixation by Clovers}

Various nutritional factors can modify nitrogen fixation, acting both through the rhizobia and host legume (Andrew, 1962). 
Acute nitrogen deficiency results where nodulation and function of root nodules are unsuccessful, owing to soil acidity, molybdenum deficiency, or the absence of effective rhizobial strains. Chronic shortage of any essential nutrient will depress nitrogen fixation by reducing growth of the host plant. Walker (1956) discussed clover responses to sulphur. R. H. Jackman (pers. comm.) showed that nitrogen fixation over a 4-month period increased from 110 to 230 units/acre as phosphorus deficiency was progressively remedied. Similarly, J. L. Brock (per. comm.) found that, while phcsphorus-deficient white clover fixed about 250 units of nitrogen/acre annually, this increased to 450 units where phosphorus was adequate. Competition by browntop for limiting phosphorus greatly reduced nitrogen fixation by white clover (R. H. Jackman, pers. comm.).

Climate modifies the effectiveness of clovers. Clover nitrogen input in Southland was only half that in the Manawatu (Sears et al.s 1953). Pertinent to the low rainfall areas of the Wairarapa, drought interferes with nitrogen fixation in much the same way as it affects plant growth generally, while extreme drought results in the loss of clover nodules (Vincent, 1965). Dry conditions in Canterbury depressed nitrogen fixation by white clover well below that in Southland or Manawatu (Sears et al., 1953). Irrigation increased clover production from 1,800 to $3,200 \mathrm{lb}$ D.M./acre during summer and autumn (Brougham and Ball, unpublished data). This represented a lift in clover herbage nitrogen, available for recycling, from 80 to 150 units/acre. Perennial legumes will not survive extreme drought, and annual clovers contribute less nitrogen 10 the soil-plant system. J. L. Brock (pers. comm.) recorded annual nitrogen fixation of suckling clover (Trifolium dubium Sibth.) as 250 units/acre, compared with 475 units for white clover.

Increasing soil nitrogen availability depresses nitrogen fixation by clovers (Bryan, 1962; Vincent, 1965), as is illustrated by the data of Sears et al. (1965). Where the return of dung and urine to grass/clover plots was simulated, net nitrogen input was 68 units per 1,000 $\mathrm{lb}$ of clover D.M. harvested. However, when herbage was removed and soil nitrogen availability was lower, net fixation increased $50 \%$ to 98 units of nitrogen per $\overline{1,0} 00 \widehat{\mathrm{lb}}$ of harvested clover. Application of 80 units/acre of nitrogen depressed subsequent fixation by white clover to about $25 \%$ of that for the control plants (Moustafa et al., 1969). 


\section{Limitations to Clover as a Source of Nitrogen}

As soil fertility (more correctly soil nitrogen availability) increases, grass dominance prevails in a mixed sward (Sears, 1960). Clovers in a developing sward fix progressively less nitrogen (Donald, 1956; Dilz, 1965). There is a decline in the bulk of clover produced, and the clover plants derive relatively more nitrogen from soil supplies. The proportion of legume nitrogen due to fixation in normal, fertile soils is commonly about $50 \%$ (Vincent, 1965).

When supplied with fertilizer nitrogen, the grass component of a developed sward invariably shows a response (Donald, 1956, 1963). Production from a grass/clover pasture appears selflimiting through nitrogen availability, within the limits set by climate, species and management. Grasses always suffer some degree of nitrogen deficiency, as lower-growing clovers will only persist in a mixed pasture under such conditions of nitrogen deficiency as restrict the growth of taller grasses, admitting light to the clovers (Donald, loc. cit.).

To raise the productivity of present pasture species beyond this point, fertilizer nitrogen must be used.

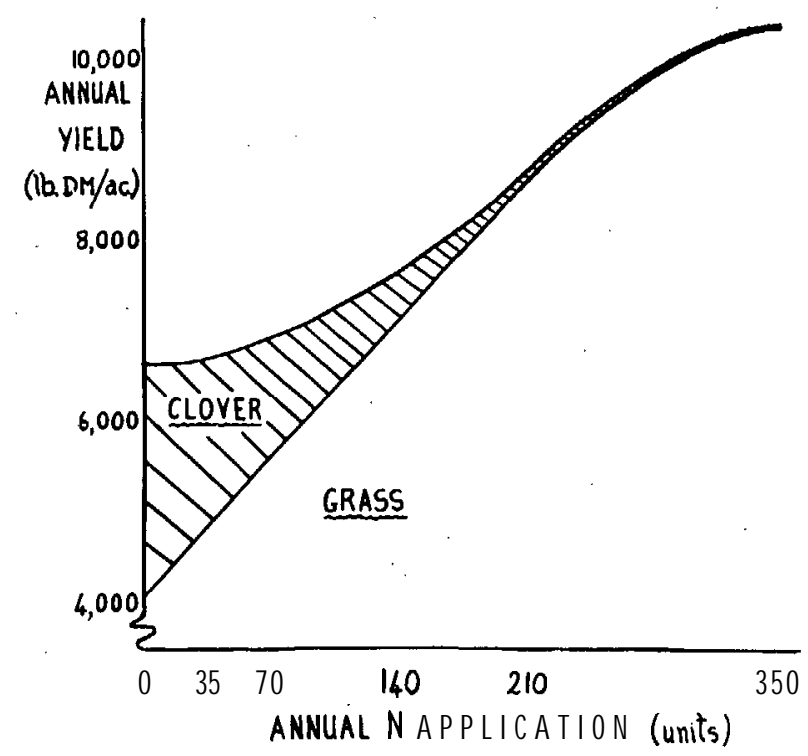

FIG. 1: Effects of increasing nitrogen applications on a grass/clover pasture. 


\section{'THE' USE OF NITROGEN FERTILIZERS FOR FORAGE PRODUCTION FROM MIXED PASTURES}

The central position occupied by nitrogen availability in determining both yield and botanical composition of mixed pastures is illustrated in Fig. 1, derived from European data (Linehan and Lowe, 1960). Small applications of nitrogen to a very clovery sward increased grass growth, but a compensatory reduction in clover growth meant little change in total yield. As nitrogen applications increased, grasses progressively replaced clovers, and overall yield responses per unit of nitrogen improved. Grasses responded linearly to about 300 units/acre of nitrogen per year. Total productivity increased from $6,600 \mathrm{lb}$ D.M./acre without nitrogen up to $10,400 \mathrm{lb}$ with 350 units, while the contribution by clovers to total yield fell from $36 \%$ to $0.3 \%$. This figure is strikingly similar in pattern to the development of soil fertility and pasture productivity in New Zealand, as discussed by Sears (1960).

Two principles emerge:

(1) There is little point in applying nitrogen to very clovery pastures; and

(2) Responses to nitrogen will be greatest on high-producing, grass-dominant swards. In New Zealand this virtually means ryegrass-dominant swards.

\section{ShORT-term RESPONSES TO NItrogen Fertilizers}

I have been working with T. R. 0. Field at Grasslands Division on pasture responses to nitrogen. My comments are confined to the use of nitrogen for forage production from pastures, the field with which I am conversant. Our data apply to a limited range of weather, soil and pasture conditions. The following interim report does not imply a general recommendation for nitrogen usage.

Trials over the past year have confirmed the view that production of grasses in a mixed pasture is limited by the inability of clovers and soils to satisfy nitrogen requirements. Provision of non-limiting nitrogen has increased grass growth and doubled total production over a range of conditions. However, our results have been variable, ranging from no to highly satisfactory responses. We would like to be in a position to predict confidently the likely response to nitrogen, and are currently investigat- 
ing some of the climatic, managerial and pastoral factors which modify these responses.

Figure 2 summarizes results from three trials in different seasons. The pasture was perennial ryegrass-dominant, and phosphorus and potassium were adequate. Production increases from 40 units/acre of nitrogen are presented for two periods of spelling after nitrogen application.

The contribution of climate to these results is outstanding. In autumn (mid-April application), 40 units of nitrogen gave a response of about $500 \mathrm{lb}$ D.M. in 4 weeks, and $650 \mathrm{lb}$ when the spell following nitrogen application was increased to 8 weeks. In winter (early June application), the response was about $100 \mathrm{lb}$ D.M. for both spelling periods, However, in spring (November application), the response at 3 weeks was almost $600 \mathrm{lb}$ D.M. and $1,200 \mathrm{lb}$ at 5 weeks. Similarly, in a grazing trial (Brougham and Ball, unpublished data) we have found that nitrogen responses are larger and predictable when nitrogen is applied during good growing conditions. When growth is severely depressed, whether by lack of sunlight and/or cold temperatures in winter, or

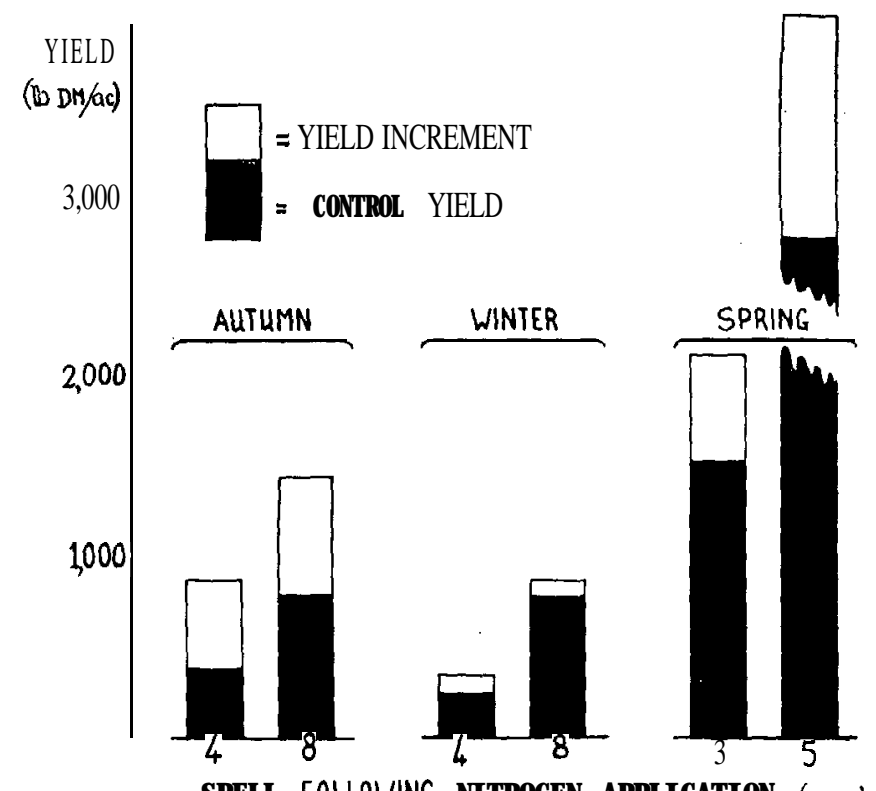

SPELL FOLLOWING N TROGEN APPLI CATI ON (weeks)

F . 2: Seasonal responses of a mixed pasture to $\mathbf{4 0}$ units of ni trogen. . 


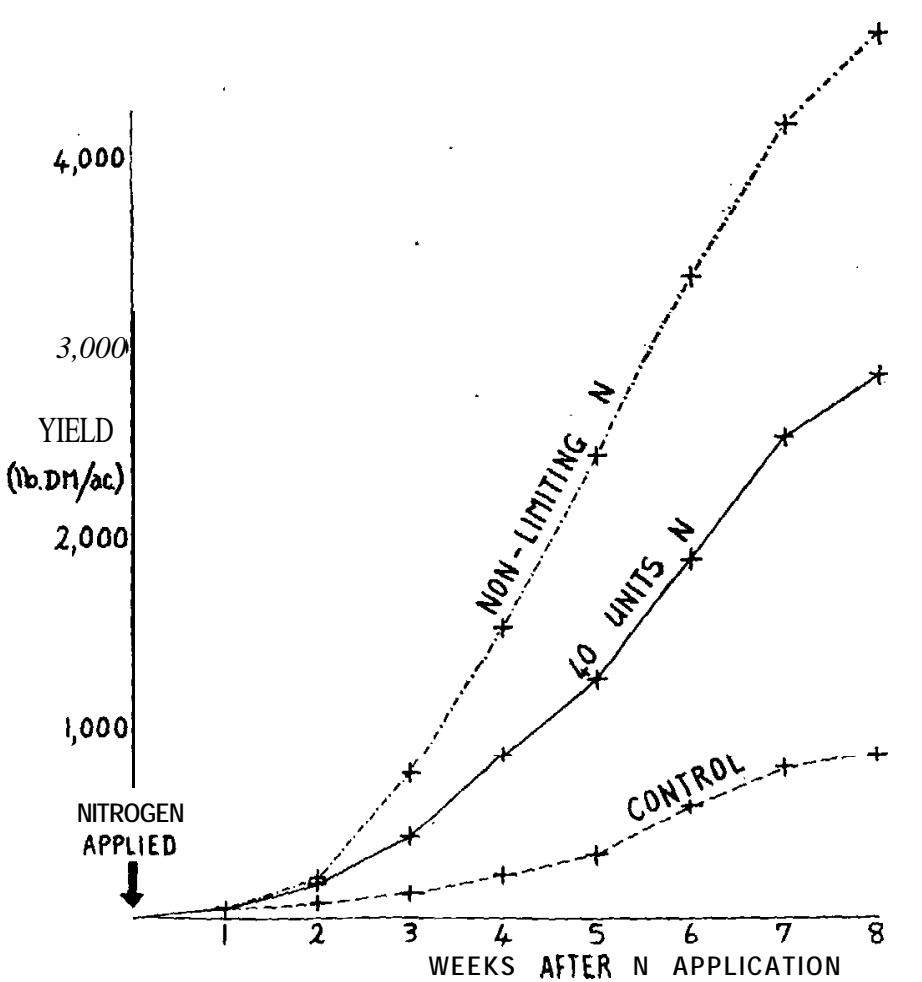

FIG. 3: Time-course of pasture response following nitrogen application.

through severe soil moisture shortage in summer and autumn, nitrogen has been comparatively ineffective.

The time lapse between nitrogen application and utilization of the herbage produced also regulates nitrogen responses, as illustrated in Fig, 3. Responses to nitrogen increased with time after nitrogen application at the end of August. In this case, the response to 40 units/acre 3 weeks after application was $7.5 \mathrm{lb}$ D.M: for each pound of nitrogen applied, but, at 8 weeks, the yield increase represented $50 \mathrm{lb}$ D.M. per pound of nitrogen.

Nitrogen responses under suitable climatic conditions are more rapid if nitrogen is used on pastures with a reasonable cover of herbage.

The foregoing data apply to pasture responses immediately following nitrogen application. Possible residual effects beyond the first harvest have been ignored. 
LONG-TERM IMPLICATIONS OF NItROgEN UsAgE ON

Mixed - PAstures

A considerable research effort is still required into the longterm implications of nitrogen usage.

When nitrogen is applied to a grass/clover association, by far the greater share is taken up by the grasses (Walker et al., 1956). That taken up by clovers has little effect on yield, as nitrogen fixation is simultaneously depressed (Dilz. 1965; Moustafa et al., 1969). Grass growth is strongly stimulated, intensifying competition for light, moisture and other nutrients, and the percentage of clover in the sward declines (Donald, 1963).

There are several reports of clover suppression and a temporary depression in total productivity following single dressings of nitrogen to mixed swards (Lynch, 1953: Walker, 1956; Donald, 1963). Consideration of available information would suggest that the followirg factors will increase the probability of clover suppression:

(1) Nitrogen application to very clovery swards;

(2) Heavy rates of nitrogen;

(3) Long spells before grazing;

(4) Inadequacy of other nutrients, especially phosphorus, potassium and sulphur; and

(5) A dry summer following spring nitrogen usage.

\section{CONCLUSIONS}

In New Zealand's comparatively equitable climate, clovers, particularly whit\& clover: grow extremely well. They provide forage of high quality and fix large amounts of nitrogen. This role of clovers is greatly modified by climate, nutrient availability, and soil nitrogen availability. Eventually a ceiling to production is envisaged, whether further increases from the present pasture species will require the use of fertilizer nitrogen.

In discussing the use of nitrogen fertilizers on pastures, I suffer the disadvantage of having very few New Zealand data. I have carefully skirted economics. The extent of nitrogen usage will be decided on economic grounds, requiring considerably more agronomic information than is currently available. First considerations would seem to preclude replacing clovers by fertilizer as the principle source of nitrogen in New Zealand's pastoral industry. 
Some 300 to 500 units/acre of nitrogen could be required annually on grass swards to equate the production obtained from well managed grass/clover associations (Sears et al., 1965; Cooke 1967) costing $\$ 20$ to $\$ 40$ per acre each year.

Nitrogen may be used intermittently for short-term stimulation of grass growth. We know something of the variables which modify these responses, and have found that satisfactory results can be obtained. However, we do not know yet whether these short-term responses are additive to annual production or partly offset by possible adverse residual effects. Until more is known of the long-term effects of periodic nitrogen application to mixed swards, the problems of subsequent pasture management must be met by the managerial skill of any farmers who elect to use fertilizer nitrogen on pastures.

\section{ACKN OWLEDGEMENTS}

I wish to thank Dr R. W. Brougham and T. R. 0. Field of Grasslands Division for agreement to my use of data from joint projects, prior to their publication, My thanks also go to technical staff, especially S. W. Crotty and T. V. Holland, for assistance with field work.' We also appreciate the co-operation of the Dairy Husbandry Department, Massey University, who provided a suitable area for our studies.

\section{REFERENCES}

Andrew, C. S., 1962: A review of nitrogen in the tropics, with particular reference to pastures. of Pastures and 'Field Crops, Hurley, Berks.: 130-46. Alden Press, Gt. Britain.

Anonymous, 1969: Biology and Ecology of Nitrogen. Proc. Conf. Production Processes Sub-committee, U.S. National Committee for the Internat. Biol. Programme, Univ. Calif., Davis, 1967: p. 1. Nat. Acad. Sciences, Washington, D.C.

Brougham, R. W., 1966: N.Z. agric. Sci., 2: I-4.

Bryan, W. W., 1962: A review of nitrogen in the tropics, with particular reference to pastures, Bull. 46, Commonw. Bur. of Pastures and Field Crops, Hurley, Berks.: 147-60. Alden Press, Gt. Britain.

Butler, G. W.; Bathurst, N. O., 1956: Proc. 7th. int. Grassld Congr.: 168 78 .

Cooke, G. W., 1967: The Control of Soil Fertility. Crosby, Lockwood \& Son, London.

Dilz., K., 1965: Stikstof No. 9: 37-45.

Doak, B. W., 1952: J. agric. Sci., Camb., 42: 162-71.

Donald, C. M., 1956: Proc. 7th int. Grassld Congr.: 80-91

, 1963: Adv. Agron., 15:. 1-13.

Linehan, P. A.; Lowe, J., 1960: Proc. 8th int. Grassld Congr.: 133-7. 
Lynch, P. B., 1953: In Proc, Waikato Nitrogen Conference: 18-20. I.C.I. (N.Z.) Ltd.

Moustafa, E.; Ball, R.; Field, T. R. O., 1969: N.Z. Jl agric. Res., 12: 691-6. O'Connor, K. F., 1966: Proc. N.Z. Grassld Ass., 28: $59-78$.

Sears, P. D., 1956: Proc. 7th int. Grassld Congr.: 92-103. 1960: Proc. 8th int G rassld Congr.: 130-3.

Sears, P. D.; Lambert, J. P.; Thurston, W. G., 1953: N.Z. Il Sci. Technol., 35A: 199-220.

Sears, P. D.; Goodall, V. C.; Jackman, R. H.; Robinson, G. S., 1965: N.Z. Jl agric. Res., 8:270-83.

Viets, F. G., 1965: In Soil Nitrogen, Agron. Series No. 10: 503-49. Amer. Soc. Agron., Inc.

Vincent, I. M., 1965: Ibid., 387-439.

Walker, T. W., 1956: Proc. 7th int. G rassld Congr.: 157-67. 1962: Trans.it Mtg Comm. IV and V int. Soc. Soil Sci.: 704-14.

Walker, T. W.; Adams, A. F. R.; Orchiston, H. D., 1956: Soil Sci., 81: 339-35 1 .

\section{DISCUSSION}

Questioned as to the environmental factors affecting the rate of uptake of nitrogen by grasses, Ball said there was little response in winter because of cold and lack of light. Untake was also limited under verv drv conditions. There was an optimum temperature for the fixation of-nitrogen by rhizobia.

During considered that $50 \mathrm{lb}$ D.M. per $\mathrm{lb} \mathrm{N}$ was rather high and suggested nitrogen deficiency. He asked if the same result could be expected again. Ball replied that the results were from a sequential cutting experiment where accelerated mineralization of nitrogen might result. He agreed that it might not be possible to repeat the result. The ryegrass in the pasture was Ariki. No other mineral constituents of the pasture were being measured.

There were few data in New Zealand on nitrogen losses under different climatic conditions. The recovery of nitrogen over a 12-month period was the objective of work at present being carried out. ,

Asked whether it would be better to apply nitrogen to species other than ryegrass, Ball replied that much more work was required on this aspect and that the final decision would probably be one of economics. 